\title{
Revenue in reverse? An examination of reverse supply chain enabled revenue streams
}

\author{
Larsen, Samuel; Jacobsen, Peter
}

Published in:

International Journal of Physical Distribution \& Logistics Management

Link to article, DOI:

10.1108/IJPDLM-03-2015-0054

Publication date:

2016

Document Version

Peer reviewed version

Link back to DTU Orbit

\section{Citation (APA):}

Larsen, S., \& Jacobsen, P. (2016). Revenue in reverse? An examination of reverse supply chain enabled revenue streams. International Journal of Physical Distribution \& Logistics Management, 46(8), 783 - 804. https://doi.org/10.1108/IJPDLM-03-2015-0054

\section{General rights}

Copyright and moral rights for the publications made accessible in the public portal are retained by the authors and/or other copyright owners and it is a condition of accessing publications that users recognise and abide by the legal requirements associated with these rights.

- Users may download and print one copy of any publication from the public portal for the purpose of private study or research.

- You may not further distribute the material or use it for any profit-making activity or commercial gain

- You may freely distribute the URL identifying the publication in the public portal 


\title{
Revenue in reverse? An examination of reverse supply chain enabled revenue streams
}

\begin{abstract}
Purpose - When original equipment manufacturers (OEMs) examine whether to implement a reverse supply chain (RSC) for their products, oftentimes the motive is cost savings or regulatory compliance. However, a frequently overlooked but equally important benefit is the possibility for creating new revenue. This paper examines which revenue streams the RSC enables for OEMs to utilize and how these streams are utilized in industrial practice.

Design/Methodology/Approach - First, the paper identifies the RSC-enabled revenue streams that are available to OEMs using a literature-based conceptual modeling approach. Second, using a set of eight cases the paper explores these streams' utilization pattern and develops a set of propositions that explain the pattern.

Findings - Results show a set of twelve distinct RSC-enabled revenue streams within three categories: 1) New revenue through sales of used items, 2) new revenue through sales of recovered items, and 3) new revenue through added sales of virgin products. Six of these twelve streams are utilized in industrial practice. Among the propositions that explain the utilization pattern are the degree of component customization, product life-cycle longevity, and the value gap between used and recovered products.

Originality/value - While extant literature concerning the relation between the RSC and the firm's revenue is scarce, this paper contributes to the understanding of RSCs' revenue generation potential and thus to the stream of literature that views the RSC as a value creator rather than a costly nuisance. Furthermore, the paper provides managers with a broad view of how their firm's RSC can increase revenue from existing markets as well as create revenue from new markets.
\end{abstract}

Keywords: Reverse supply chain; reverse logistics; revenue; OEM; conceptual modeling, case study research

Paper type: Research Paper

\section{Introduction}

While the customer is the end-destination in traditional forward supply chains, reverse supply chains (RSCs) begin with the customer. In the RSC-concept by Guide and Van Wassenhove (2009) the RSC consists of five connected processes: 1) Product acquisition, which concerns acquiring used products from the market (used products are labeled core products in literature); 2) reverse logistics, which concerns the logistical movement of core products from the market to a sorting facility; 3) inspection, sorting, and testing of products to determine quality and choice of recovery operation; 4) recovery operation (e.g. repair, remanufacturing, or recycling); and 5) remarketing, which concerns creation and exploitation of markets for recovered products. Figure 1 illustrates the RSC.

4. Recovery operation

3. Inspection, sorting, and testing

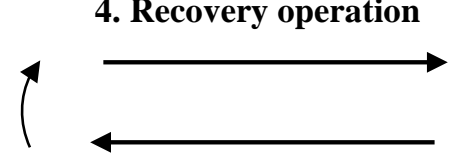

2. Reverse logistics
5. Remarketing

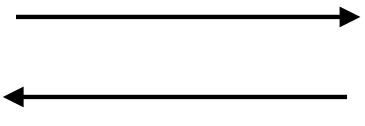

1. Product acquisition

Figure 1 - Illustration of the RSC (Guide and Van Wassenhove, 2009) 
In academia the RSC has traditionally been seen as a "costly sideshow to normal operations", "an unwanted stepchild of forward logistics”, and "a nuisance, or worse, trash” (Stock et al., 2002; Mollenkopf and Closs, 2005; Guide and Van Wassenhove, 2009). Consequently, the literature within the RSC-field has up until the mid-2000s largely been a discipline concerned with reduction of costs (e.g. Gungor and Gupta, 1998; Ilgin and Surendra, 2010). However, a different literature stream, labelled the "business perspective" on the RSC, has emerged in the RSC-field. In this stream, where focus is on how the RSC can generate value for the firm (Guide and Van Wassenhove, 2006), RSCs are viewed as "potentially profitable business propositions” (Guide and Van Wassenhove, 2009).

A recent paper by Huscroft et al. (2013), which sets a future research agenda for the RSC-field, expresses the need for scholarly attention to the RSC as a profit-center. A recurring challenge in examining the financial impact of the RSC is the assessment of the RSC's revenue impact (Thierry et al., 1995; Mollenkopf and Closs, 2005). How to identify and utilize sources of RSC-enabled revenue are problems that transcend the functional boundary between marketing and operations/logistics. They call for cooperation between the communities of marketing research, on the one hand, and operations management research, on the other. Although the marketingoperations interface has received considerable attention (e.g. Tang, 2010), the particular relationship between marketing and RSC-operations is not well-examined (e.g. Ilgin and Surendra, 2010). According to Guide and Van Wassenhove (2009) there is a current lack of interest in marketing research communities to investigate RSC-topics. Indeed, searches for RSC and related terms in marketing journals show that the topic is rarely dealt with. A recent special issue of Industrial Marketing Management acknowledges the literature gap (Lee and Lam, 2012; Chan et al. 2012).

The purpose of this study is to investigate the relationship between the RSC and the firm's revenue streams by systematically examining 1 ) which revenue streams the RSC enables the firm to utilize and 2) how these streams are utilized in industrial practice. Answering these questions will contribute to a better understanding of the value that the RSC can provide the firm, which is the crux of the RSC business perspective.

\section{Domain Limitation}

The study's domain is limited to original equipment manufacturers (OEMs) defined roughly as Karlsson (2003) and Geyer and Jackson (2004): The firm conducts end-product assembly and fabrication of some components in-house, while remaining components and all materials are sourced. Consequently, the firm has its competences in component manufacturing and end-product assembly, but not within manufacturing of materials. The firm has a primary market for endproducts and an aftermarket for components, both of which are technically recoverable. This paper will refer to a firm that fits this description as the "focal OEM". Figure 2 illustrates the focal OEM within its forward supply chain. The figure is structured as four vertical supply chain stages and the dotted square marks the boundaries of the focal OEM.

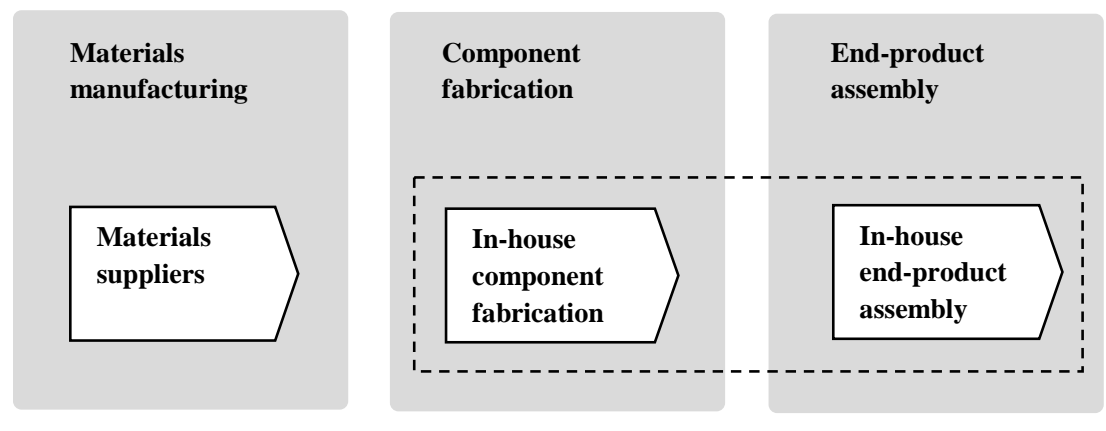

Figure 2 - The focal OEM within its forward supply chain

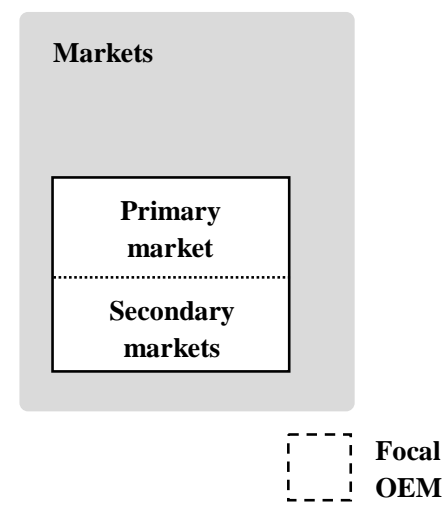


The RSC-literature typically differs between OEMs and Independent Recovery Firms (IRFs), which collect, recover, and resell products that are originally manufactured by the OEM. IRFs, though addressed in the literature review, are not within the paper's domain limitation.

The paper is organized as follows. First, the paper reviews literature and details the methodology. Second, the paper identifies streams of RSC-enabled revenue and examines their industrial utilization. Third, conclusions, contributions to theory and practice, limitations, and suggestions for further research are presented.

\section{Literature review}

This section reviews literature addressing how firms can achieve revenue through their RSC. The review is divided into two sections about 1 ) revenue enabled directly through the firm's disposition strategies for core products, and 2) revenue through added virgin product sales enabled by the RSC. A virgin product means a product entering the market for the first time made from virgin components and materials.

\section{Revenue through the firm's disposition strategies}

Skinner et al. (2008) defines disposition strategy as an option a firm has regarding what to do with a returned product. Simply throwing the product into the trash bin is an example of a disposition strategy. Trashing the product may, however, not be the most economical option for the firm. Typically, the firm has a set of disposition strategies available. The purpose of this section is to examine the revenue-generating strategies within such a set. The section reviews disposition strategies available to OEMs and the potential within these disposition strategies for revenue generation.

Thierry et al. (1995) divide disposition strategies that are available to OEMs into three categories: 1) direct reuse, 2) product recovery, and 3) disposing of products through the waste stream. Other papers see materials recycling as a fourth distinct category (e.g. Guide and Pentico, 2003). Given this paper's focus on revenue generation, this section examines the disposition strategies within the categories of product recovery and materials recycling, while omitting direct reuse and waste streams. Direct reuse is omitted because directly reusable products, which are resold through the firm's traditional primary channel, do not lead to added revenue, because the resale cannibalizes the sale of a virgin product. Instead, the firm's benefit is avoiding the cost of manufacturing a virgin product.

The product recovery category covers a range of disposition strategies. Thierry et al. (1995) lists three strategies that apply to complete end-products: repair, refurbishing, and remanufacturing. Common for these three strategies is that if recovered products can be resold to either currently unaddressed segments in the firm's primary market or to secondary markets while omitting virgin product cannibalization, then the strategies can provide new revenue for the firm.

Literature does not associate materials recycling with revenue generation, but rather with regulatory compliance (e.g. Pagell et al., 2007). However, while materials manufacturing processes (including recycling) are outside the focal OEM's upstream boundary, take-back and resale of core materials could be a source of new revenue. In general, a group of potentially revenue-generating disposition strategies that are unexplored in literature concern taking back any core item for resale without recovering the item. Such strategies resemble direct resale, but direct resale presupposes new and fully functioning products. Resale of core items includes all processes in Guide and Van Wassenhove's RSC-concept depicted in Figure 1 except for the recovery operation.

Common for all revenue generating disposition strategies is that each strategy addresses a buyer group. Srivastava and Srivastava (2006) define two sets of buyer groups: 1) A firm's primary market that is an outlet for sales of virgin products and 2) a firm's secondary markets that are outlets for sales of recovered products. This paper also distinguishes between these two sets of buyers, but the paper argues that the primary market may also be an outlet for recovered products. 
In general, the paper applies a detailed view of buyer groups. For example, there may be one distinct buyer group for recovered end-products, a second buyer group for core end-products, a third for recovered components, a fourth for core components, etc.

In extant literature the most described revenue generating disposition strategy is end-product remanufacturing and the most described purpose of end-product remanufacturing is resale of recovered products to the firm's primary market (e.g. Atasu et al., 2008). According to remancentral.com 73.000 firms conduct product recovery realizing revenue of \$53 billion. One explanation is that offering remanufactured products has market expansion effects (Souza, 2012). According to Debo et al. (2006) a recovered product can be a cheaper substitute for the virgin product, which makes the OEM able to gain market share among price-sensitive customers and prevents low-cost competition from market-entry (Atasu et al., 2010). Resale of recovered products is especially attractive to an OEM if their market has a large green segment that values product recovery or when the market has fierce competition, where recovered products, which function as a low-price product-line extension, can cannibalize competitors' sales (Atasu et al., 2008).

Resale to secondary markets can also generate additional revenue (Tibben-Lembke, 2004). For this purpose the OEM typically takes back from the primary market products containing older technology (Robotis et al., 2005). Resale of core products to IRFs without recovery is not wellexamined in academic literature. However, some papers discuss competition between the original manufacturer of a product and IRFs (e.g. Ferrer and Swaminathan, 2006) indicating a potential revenue-generating opportunity for the OEM to take back products for the purpose of resale to IRFs. Often IRFs can conduct product recovery for lower costs than the OEM (Chen and Chang, 2012) opening an opportunity for the OEM to take back and resell cores to IRFs, utilizing their knowledge of the core products' locations and age. A number of third-parties (e.g. brokers and salvage auctioneers) can act as "middle men" between the focal OEM and secondary market customers (e.g. Tibben-Lembke, 2004; Clottey and Benton, 2014).

Resale of core or recovered components is not thoroughly explored in academic literature although Thierry et al. (1995) describe a case study of a copy-machine OEM, where resale of core components back to original suppliers is a substantial part of the OEM's (very successful) RSC. Revenue streams from component resale may have higher potential with the increasing use of standard components. Markets for standard components could include 1) the OEM's direct endproduct competitors and 2) "related" manufacturers, who produce products that contain the same components.

Recycling of core materials takes place when high-value recovery options (e.g. repair and remanufacturing) are depleted (Kocabasoglu et al., 2007). Literature suggests that profitability within materials recycling is very difficult to achieve for individual firms (e.g. Pagell et al., 2007). One possible explanation is that OEMs typically do not produce virgin materials in-house, but instead purchase materials from suppliers. Consequently, the OEM has neither competencies nor equipment for core materials recovery. If in-house recycling is not an option, two potential revenue streams become available: Resale of core materials to independent recyclers (Simpson, 2010) and the unexplored revenue stream of reselling core materials back to their original supplier. When the original supplier of a material becomes the buyer of that material, then the material is well-known by the buyer and has the right specification for the buyer's internal reuse (e.g. the right chemical mix or type of metal alloy). Therefore, the value of core materials will be higher to the original material supplier than to an independent recycler.

New revenue through added virgin product sales enabled by the RSC In addition to generating revenue through the OEM's disposition strategies, the RSC enables added revenue through increased virgin product sales. Although difficult to measure, the RSC enables added revenue through both retention of current customers and attraction of new customers (Jayaraman and Luo, 2007). The following two paragraphs detail how. 
RSCs enable the OEM to add services to their product offering. According to Oliva and Kallenberg (2003) competing on services that are integrated into a manufacturer's total product offering has long been a strategy suggested by academia. Adding services increases the value of the total product offering and enables the OEM to charge higher prices, gain market share, or both (Cohen et al., 2006). Given that adding services to the total product offering yields added revenue, the question is which revenue-yielding services the RSC enables. Literature contains several examples: repair services (Cohen et al., 2006), a liberal return policy (Jack et al., 2010), EOLproduct take-back (Prahinski and Kocabasoglu, 2006), and an extended product warranty that includes remanufacturing of a product or free replacement of a defective product with a remanufactured product (Souza, 2012).

A "green" brand image is a well-examined RSC-enabled driver of revenue. A strong brand image creates customer loyalty, barriers against competitor entry, and higher willingness-to-pay among buyers (Mollenkopf and Closs, 2005; Jayaraman and Luo, 2007; Kotler and Keller, 2009). Corporate citizenship, green manufacturing, and environmental responsibility are all examples of brand image components that drive new revenue from green consumer segments. A RSC can contribute to an OEM's green brand image because it reduces waste and reuses materials (Atasu et al., 2008).

Integrating RSC-enabled services into the firm's total product offering and augmenting brand image associations lead to new revenue through increased virgin product sales. These two revenue increasing opportunities are available to OEMs in addition to the revenue streams achievable through the firm's disposition strategies.

\section{RSC-enabled revenue streams - summary of literature}

As the literature describes, RSC-enabled revenue can be captured by 1) reselling recovered items, 2) reselling un-recovered items, 3) offering RSC-enabled services, and 4) augmenting brand associations. While the RSC enables two distinct opportunities for increasing virgin product sales, the RSC enables a whole range of possible revenue streams through the firm's disposition strategies. Following the literature these streams can be defined using the three constituent elements of item, disposition strategy, and buyer group. Using these three constituent elements as dimensions in a three-dimensional matrix, Figure 3 captures all potential revenue streams. The content of each axis is drawn from the literature review. The figure contains 84 revenue streams (three items times four disposition strategies times seven buyer groups).

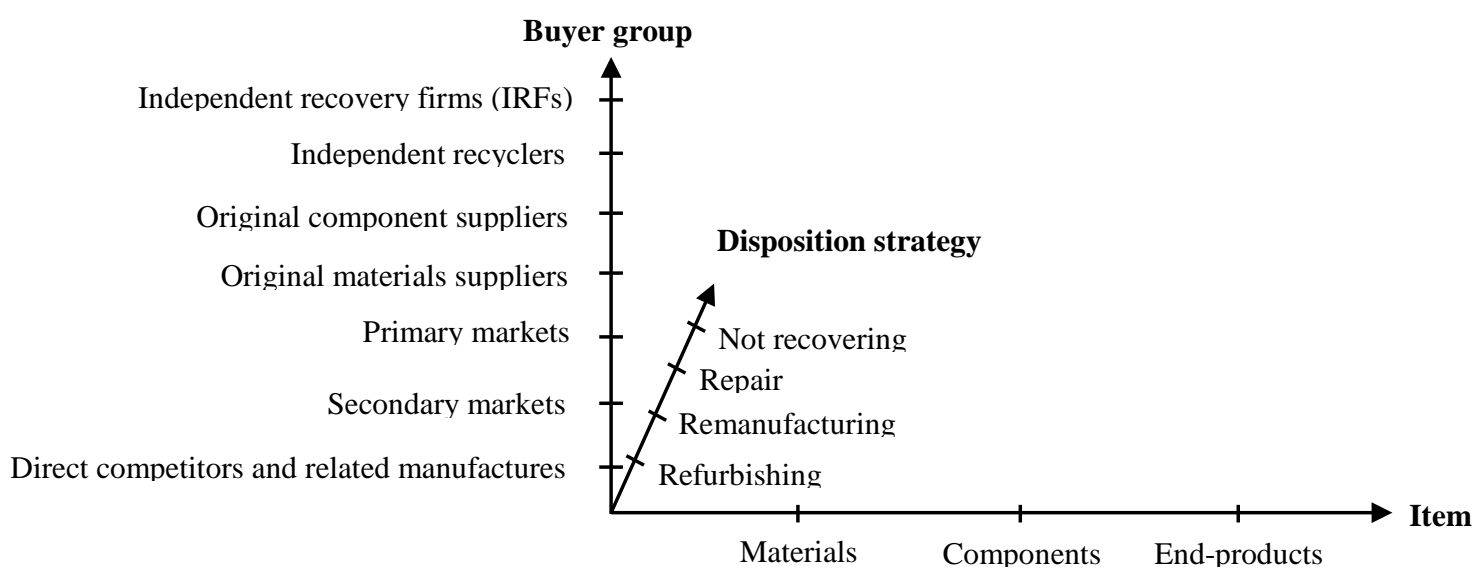

Figure 3 - The three dimensions that capture 84 potential revenue streams

After delineating the research methodology the paper first discusses the identified revenue streams analytically by excluding illogical streams from the set. Second, the paper assesses the real- 
life viability of utilizing the remaining logical revenue streams using the empirical case study that examines the revenue streams' industrial utilization.

\section{Research methodology}

The paper's objective is to identify the revenue streams enabled by the RSC and examine the industrial utilization of these streams. To reach this objective the study uses 1) a literature-based conceptual modeling approach that identifies RSC-enabled revenue streams and 2) a multiple case study that examines industrial utilization. The following sections detail the methodology.

\section{Identification of RSC-enabled revenue streams using conceptual modeling}

To identify which RSC-enabled revenue streams are logically available to OEMs, the paper discusses the revenue streams that the literature review identified. The paper uses a conceptual modeling approach that lies within the category of analytical conceptual research (Meredith, 1993; Wacker, 1998). Specifically, the approach excludes illogical revenue streams, which the following paragraph details.

Every revenue stream includes a buyer and a seller. The seller is in every case the focal OEM, while buyer groups are IRFs, independent recyclers, primary market customers, etc. Consider the following revenue stream: "Resale of core materials to the OEM's primary market customers". The focal OEM's primary market customers are firms that purchase the OEM's complete end-products for use in their own operation. The revenue stream is illogical because these firms are not potential buyers for core materials. Another example of an illogical revenue stream is resale of recovered materials to independent recyclers. This revenue stream is illogical because independent recyclers' raison-d'être is recycling materials. These firms are therefore not buyer groups for materials that are already recycled.

The result of this analytical approach is a set of RSC-enabled revenue streams that are logically available to OEMs. The empirical case study that follows this analytical approach examines the industrial utilization of revenue streams and sheds light on whether these logically available streams are available in reality as well.

\section{Examining the utilization of RSC-enabled revenue streams through case study research} The examination of revenue stream utilization consists of 1) identifying the pattern in revenue stream utilization and 2) exploring the variables that explain the pattern. The case study method is chosen because it enables investigation of a focused phenomenon using contextually rich data from real-world settings and is applicable where researchers have limited or no control (Mollenkopf et al., 2007; Barrat et al., 2011). Furthermore, case study research enables examination of actual practice and allows for deep understanding of the nature and complexity of the research phenomenon (Meredith, 1989; Voss et al., 2002). The following paragraphs delineate 1) the case study's unit of analysis and sampling logic, 2) data collection methods and instrumentation, 3) methods of analysis, and 4) reflections on the chosen method's validity.

The case study's unit of analysis is the physical and monetary flows in each case firm's RSC. These flows are examined for a sample of eight cases. Multiple cases allow for the use of replication logic that strengthens the findings' transferability (da Mota Pedrosa et al., 2012; Miles et al., 2014; Yin, 2014). The sample of case firms is chosen using the following criteria:

1. The firm conducts end-product assembly and fabrication of some components in-house, while remaining components and materials for in-house manufactured components are sourced

2. The firm's end-products and in-house fabricated components are technically recoverable

3. The firm sells components as spare parts in addition to their normal product sales 
This set of criteria is extracted from the description of the paper's focal OEM detailed in the paper's domain limitation in the Introduction. While the set of criteria concerns the selection of individual cases, the paper includes an additional selection criterion that applies to the totality of cases:

4. Collectively, the set of cases must contain variety with respect to industry and firm size

Variety broadens the external validity of findings. The paper ensures variety within the sample by choosing four medium-sized and four large case firms from eight different industries. Differences in industry imply differences in, for example, customer requirements, product technologies, product sizes, and logistical set-ups, which may expose distinct observations (Liebl et al., 2016). Firm-size and industry variety enable examination of similarities and differences across cases, which makes theoretical generalizations possible (Ketokivi and Choi, 2014; Miles et al., 2014). The case firms are all headquartered in either Europe or the USA, which may skew results geographically. However, all case firms have sales and operations on three or more continents, which reduces this risk. Table 1 details the sample of cases.

Table 1 - Case firms

\begin{tabular}{|l|l|l|}
\hline Case & \multicolumn{1}{|c|}{ Industry } & \multicolumn{1}{c|}{ Size } \\
\hline Case 1 & Industrial measurement equipment & Medium \\
\hline Case 2 & Ship engine equipment & Large \\
\hline Case 3 & Industrial heating equipment & Large \\
\hline Case 4 & Water distribution equipment & Large \\
\hline Case 5 & Hearing aids & Medium \\
\hline Case 6 & Electronic audio equipment & Medium \\
\hline Case 7 & Medical equipment & Medium \\
\hline Case 8 & Industrial processing equipment & Large \\
\hline
\end{tabular}

The case study's data collection has four objectives: 1) to develop a broad understanding of each case firm's forward supply chain, products, and markets; 2) to identify the physical and monetary flows in each case firm's RSC; 3) to identify revenue streams utilized; and 4) to investigate reasons for each case firm's current revenue stream utilization and non-utilization. To meet each of these four objectives the study collects data using semi-structured interviews with key employees as the primary collection method. The interviews are semi-structured because addressing each of the four objectives requires differing degrees of interview guide structure. Objectives 1, 2, and 3 are reached using a structured set of questions that address RSC-flows and revenue stream utilization. These questions are based on Guide and Van Wassenhove's RSC-concept and the set of revenue streams identified through the literature-based conceptual modeling approach. Objective 4 is reached through a loosely structured discussion concerning the reasons underlying each firm's utilization. This discussion is conducted without $a$ priori theory and instead applies the traditional principle for inductive case study research that explanation (theory) is derived from exploration (Ketokivi and Choi, 2014).

The interviews were recorded and conducted as on-site face-to-face meetings. The recordings enabled the researchers to listen through the interviews several times to ensure a correct understanding of each case firm's RSC and to prepare and ask follow-up questions, which were subsequently posed via telephone or email. Interviews averaged one hour in length. Interviewees were middle-managers with titles depending on each case firm's organization and size. Title examples are "supply chain director”, "director of returns”, "sales manager for used products”, "director of customer service and spare parts", and "project manager for process excellence".

In addition to interviews, the study applies written descriptions of case firms, product descriptions, and (for five of the eight cases) observations (e.g. plant tours and/or examination of 
core and recovered products). Combining these data sources with interviews allows for data source triangulation (Miles et al, 2014). The amount of data necessary for achieving data saturation differs across cases depending on how many RSC-enabled revenue streams each case firm utilizes.

The case study applies both within-case and cross-case analysis (Miles et al., 2014; Yin, 2014) using the analytical sequence illustrated in Figure 4. First, the study identifies RSC-flows and revenue stream utilization within cases; second, the study identifies explanatory variables for revenue stream utilization also within cases; third, the overall utilization pattern across the eight case firms is analyzed; fourth, the paper discusses whether within-case explanatory variables can explain the cross-case pattern. The fourth step develops a set of propositions that connect explanatory variables with the cross-case utilization pattern and apply to OEMs beyond the case sample.

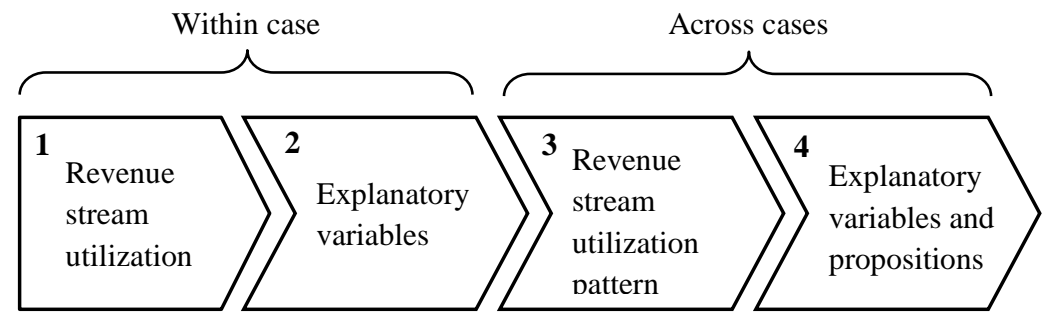

Figure 4 - Analytical sequence

When the case study's research design was developed, the study had two particular challenges for ensuring the internal validity of findings: 1 ) among the multitude of activities within each case firm to delimit the particular processes that constitute each firm's RSC, and 2) among the multitude of processes that constitute each firm's RSC to delimit the processes that lead to revenue and exclude the processes that lead to other benefits (e.g. cost savings). To tackle these challenges Miles et al. (2014) suggest 1) a clearly specified basic paradigm and 2) congruence between research questions and interviewees. As the basic paradigm his study has used the RSC-concept by Guide and Van Wassenhove (specified in the paper's introduction) and to ensure congruence the study has invested a considerable effort in determining which roles in each case firm possess the information relevant for the study. The effort ensured 1) a clear understanding of which processes constitute a RSC and 2) a set of interviewees with the best possible insight into reverse logistics, recovery operations, resale procedures, etc.. This resulted in clarity and a clear grasp of issues during interviews.

To strengthen the external validity of the study's conclusions (Yin, 2014) the study used the following techniques devised by Miles et al. (2014): clear criteria for case selection, a clear limitation of the study's domain, a theoretically diverse sample, and descriptions of findings "thick" enough to allow readers to assess the study's transferability into their own context. In addition, the study 1) applied cross-case analysis resulting in findings that "transcend the particular" (Miles et al., 2014) and 2) developed a set of propositions that enables testing the external validity in future research.

\section{Identification of RSC-enabled revenue streams using conceptual modeling}

As detailed in the methodology section this section excludes illogical revenue streams to ensure a set of revenue streams that are logically available to OEMs. To conduct the exclusion the study formally defines a RSC-enabled revenue stream as "a continuous stream of income received by a firm from resale of items processed in the firm's RSC or from added virgin product sales enabled by the RSC". The definition contains two types of revenue, which fits with results of the literature review: 1) revenue achieved through the RSC's dispositions strategies and 2) revenue enabled by either the integration of RSC-enabled services in the total product offering or RSC-enabled 
augmentation of brand associations. The first type of revenue ("a continuous stream of income received by a firm from resale of items processed in the firm's RSC ") has three constituent elements congruent with the three dimensions in Figure 3: item, disposition strategy, and buyer group. Any combination of item, disposition strategy, and buyer group constitutes a revenue stream. The definition of the second type of revenue ("a continuous stream of income received by a firm... from added virgin product sales enabled by the RSC") focuses not on items, buyer groups, and disposition strategies. Instead, in the second type, a revenue stream is defined by an explanation of how the RSC enables new revenue through increased virgin product sales.

RSC-enabled revenue streams available to the OEM through the firm's disposition strategies As presented in the literature summary, an OEM has 84 RSC-enabled revenue streams available (three items * four disposition strategies * seven buyer groups). The four disposition strategies are repair, refurbishing, remanufacturing, and non-recovery (take-back and resale of items without recovery). If an OEM chooses to recover, the firms must decide whether to repair, refurbish, or remanufacture. The decision has major consequences for the quality of the finished item (Thierry et al., 1995), so the choice of strategy implicitly selects the buyer group as well. For example, remanufacturing may attract primary market customers, while repair may only attract secondary market customers. Choosing not to recover also has implications for possible buyer groups. For example, primary market customers, who use the OEM's products within their own operations, are not potential buyers for core products. To utilize any particular revenue stream the OEM must choose the strategy that best matches the buyer group's purchasing criteria. In short, the choice of disposition strategy depends on the choice of buyer group and is not a separate decision. Consequently, a RSC-enabled revenue stream's constituent elements are reduced to item and buyer group. Items can be resold in either core or recovered condition. Table 2, which organizes the component parts in this discussion, presents six sellable items horizontally and seven buyer groups vertically. Each intersection constitutes a revenue stream by pairing item with buyer group. Revenue streams resulting from resale of core items are grouped in Category A, while revenue streams resulting from resale of recovered items form Category B. The whole table contains 42 revenue streams.

Table 2 - RSC-enabled revenue streams

IRFs

Independent recyclers

Original component suppliers

Original material suppliers

Primary markets

Secondary markets

Direct comp. and related man.

\begin{tabular}{|l|l|l|l|l|l|l|}
\cline { 2 - 7 } \multicolumn{2}{c|}{} & \multicolumn{3}{c|}{ Category A } & \multicolumn{3}{c|}{ Category B } \\
\hline 1 & & & & & & \\
\hline 2 & & & & & & \\
\hline 3 & & & & & & \\
\hline 4 & & & & & & \\
\hline 5 & & & & & & \\
\hline 6 & & & & & & \\
\hline 7 & & & & & & \\
\hline & Materials & $\begin{array}{c}\text { Compo- } \\
\text { nents }\end{array}$ & $\begin{array}{c}\text { End- } \\
\text { products }\end{array}$ & Materials & $\begin{array}{c}\text { Compo- } \\
\text { nents }\end{array}$ & $\begin{array}{c}\text { End- } \\
\text { products }\end{array}$ \\
\cline { 2 - 6 } & \multicolumn{3}{|c|}{ Core } & & \multicolumn{3}{c|}{ Recovered } \\
\cline { 2 - 6 }
\end{tabular}

The following section discusses each revenue stream in Table 2 beginning with the streams in row 1 and 2 concerning IRFs and independent recyclers. Independent recyclers recover materials, while IRFs recover components and end-products. Independent recyclers are therefore buyers of core materials, while IRFs purchase core components and end-products. The two buyer groups are, however, not buyers of any other items, which excludes the revenue streams in Category B in row and 2 as well as sales of core materials to IRFs in row 1, and sales of core components and core 
end-products to independent recyclers in row 2. Original material suppliers and original component suppliers are buyers of core materials and core components, respectively. They do not, however, purchase other items, which excludes revenue streams in rows 3 and 4 except for resale of core components to original component suppliers and resale of core materials to original materials suppliers. The OEM's primary and secondary markets are buyers of recovered end-products and recovered components, but for no other items, which excludes revenue streams in rows 5 and 6 except for resale of recovered end-products and recovered components to primary and secondary market customers. Direct competitors and related manufacturers produce their own end-products and are therefore potential buyers of recovered components, which they can use in their end-product assembly and for servicing their installed base. Direct competitors and related manufacturers are not, however, buyers of end-products. They might be buyers of recovered materials for their inhouse manufactured components, but recovering materials lies outside the upstream boundary of the focal OEM. Revenue streams in row 7 are therefore excluded except for resale of recovered components.

Table 3 shows the result of the exclusion of illogical revenue streams. The remaining number of RSC-enabled revenue streams is 10 (five within Category A and five in Category B). Revenue streams are denoted A1, A2, etc.

Table 3 - RSC-enabled revenue streams

IRFs

Independent recyclers

Original component suppliers

Original material suppliers

Primary markets

Secondary markets

Direct comp. and related man.

\begin{tabular}{|c|c|c|c|c|c|c|}
\hline & \multicolumn{3}{|c|}{ Category A } & \multicolumn{3}{|c|}{ Category B } \\
\hline 1 & & A1 & A2 & & & \\
\hline 2 & A3 & & & & & \\
\hline 3 & & A4 & & & & \\
\hline 4 & A5 & & & & & \\
\hline 5 & & & & & B1 & B2 \\
\hline 6 & & & & & B3 & B4 \\
\hline 7 & & & & & B5 & \\
\hline & Materials & $\begin{array}{l}\text { Compo- } \\
\text { nents }\end{array}$ & $\begin{array}{c}\text { End- } \\
\text { products }\end{array}$ & Materials & $\begin{array}{c}\text { Compo- } \\
\text { nents }\end{array}$ & $\begin{array}{c}\text { End- } \\
\text { products }\end{array}$ \\
\hline & \multicolumn{3}{|c|}{ Core } & \multicolumn{3}{|c|}{ Recovered } \\
\hline
\end{tabular}

RSC-enabled revenue through added virgin product sales

Category A and B delineate how the focal OEM can achieve new revenue through the firm's disposition strategies. The literature review also describes how the RSC enables new revenue through added virgin product sales. These opportunities for creating new revenue, which the following paragraph discusses, are grouped within Category C.

The study assumes a correlation between a product's sales performance and its market attractiveness, which means that new revenue can be driven by increasing a product's market attractiveness. According to Kotler (2000) the market attractiveness of a product is determined by the customer's perception of the product's features, quality, price, and mix of services attached to the product. As mentioned in the literature review, the RSC enables OEMs to add services to the service mix. The revenue that these services drive constitutes a RSC-enabled revenue stream, which the paper labels revenue stream C1. Customers' perception of a product's features and quality are influenced by a product's brand image associations that can translate directly into reasons-to-buy (Aaker, 1991). The RSC enables OEMs to refine their brand image by including environmental responsibility among the brand's associations. The revenue that these brand image associations drive constitutes a RSC-enabled revenue stream, which the paper labels revenue stream C2. 
RSC-enabled revenue streams in Category $A, B$, and $C$

The total number of distinct RSC-enabled revenue streams identified in this study is 12 . Figure 5 places the revenue streams in the supply chain of the focal OEM. Similar to Figure 2 that illustrates the paper's focal OEM, the dotted square shows the boundaries of the focal OEM. The twelve codes (A1, A2, etc.) each represent one RSC-enabled revenue stream. The arrows in the figure symbolize where in the OEM's supply chain each RSC-enabled revenue stream originates (where the sellable item is "produced") and points towards a buyer group.

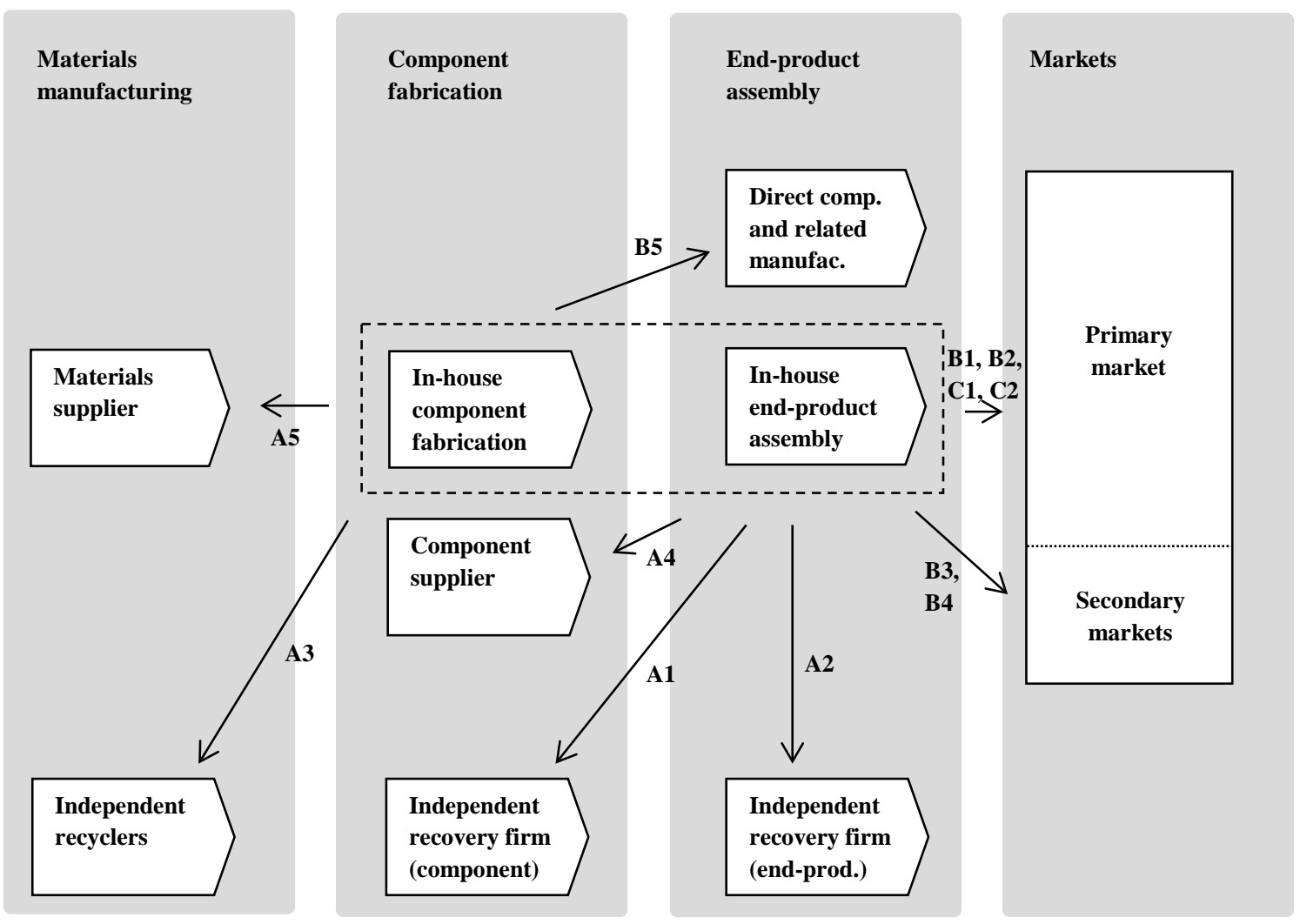

Figure 5 - Twelve revenue opportunities for the focal OEM

\section{Examining revenue stream utilization in industrial practice using case study research}

While the set of revenue streams identified in the previous section answers the first research question about which revenue streams the RSC enables, this section answers the second research question about how revenue streams are utilized in industrial practice. The next four subsections, which present the paper’s case analysis, follow the analytical sequence detailed in Figure 4.

Revenue stream utilization within each case

The study identifies utilized streams within each case. While it would be impractical to show the utilization of all case firms, Figure 6 exemplifies the revenue stream utilization of two cases. Later in the paper, the study presents an overview of all case firms' revenue stream utilization in a tabular format. 


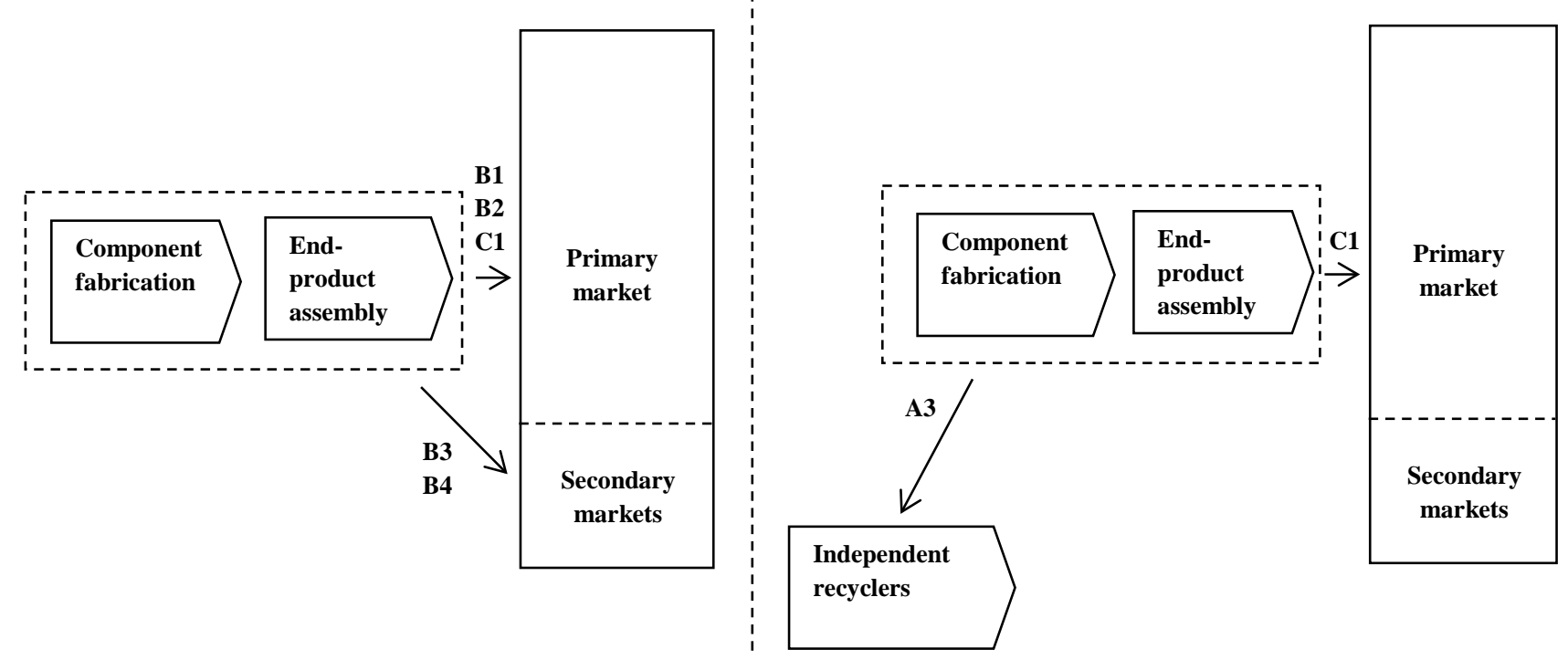

Figure 6 - Revenue stream utilization for two selected cases

Explanatory variables for revenue stream utilization within each case

This section explains each case firm's revenue stream utilization. The section examines why any given stream is utilized or not utilized. The interviewees' answers led to a set of variables that explain the revenue stream utilization within each case. Table 4 shows the set of variables in the right-hand side column. The middle column summarizes interviewees' explanations, which are either for utilization or for non-utilization. The parentheses denote the revenue stream(s) to which explanations apply. Interviewees did not have clear reasons for their utilization choice for all revenue streams, but often used statements such as "We haven't explored the opportunity", "It is an interesting thought”, "All ideas are welcome”, etc. The identified variables are used later in the paper to explain the pattern of revenue stream utilization across cases. 
Table 4 - Variables explaining revenue stream utilization

\begin{tabular}{|c|c|c|}
\hline Case & Explanations for revenue stream utilization within case & Variables explaining utilization \\
\hline 1 & $\begin{array}{l}\text { - The value gap between core products and recovered products is } \\
\text { large (B1-5) } \\
\text { - Products can be recovered at lower costs than virgin product } \\
\text { manufacturing (B2 and B4) } \\
\text { - With one exception the value of components is too low for take- } \\
\text { back and resale feasibility (A1 and A4) } \\
\text { - The reverse flow of products is low (A3-5) } \\
\text { - Sales to IRFs would inhibit control over product quality and } \\
\text { entails risk for the firm's brand (A1-2) }\end{array}$ & $\begin{array}{l}\text { - Value gap between core and recovered } \\
\text { product } \\
\text { - Virgin product manufacturing cost } \\
\text { - Value of individual components } \\
\text { - Reverse flow volume } \\
\text { - Risk for brand value of recovered } \\
\text { product quality }\end{array}$ \\
\hline 2 & $\begin{array}{l}\text { - Competition forces offering take-back of defect products for an } \\
\text { extended period of time as a service (C1) } \\
\text { - Customized products makes it difficult to find customers for } \\
\text { products outside current markets (A2, B2 and B4) } \\
\text { - Product life-cycles are long, which enables resale of recovered } \\
\text { components (B1) }\end{array}$ & $\begin{array}{l}\text { - Customers' valuation of RSC-enabled } \\
\text { services } \\
\text { - Degree of product customization } \\
\text { - Product life-cycle longevity }\end{array}$ \\
\hline 3 & $\begin{array}{l}\text { - Products are highly customized to fit each customer, which } \\
\text { hinders recovery and resale to different customers (A2 and B4) } \\
\text { - Products are large and heavy and are located far away from } \\
\text { potential sorting and recovery facilities (B2 and B4) } \\
\text { - Repair and spare part service is essential for virgin product sales } \\
\text { (C1) }\end{array}$ & $\begin{array}{l}\text { - Degree of product customization } \\
\text { - Core product “physics” } \\
\text { - Core product accessibility } \\
\text { - Customers' valuation of RSC-enabled } \\
\text { services }\end{array}$ \\
\hline 4 & $\begin{array}{l}\text { - The lack of quality control if selling core items to IRFs poses } \\
\text { risks for the firm's brand value (A1-2) } \\
\text { - A large reverse flow of products makes disassembly and resale of } \\
\text { core materials to recyclers feasible (A3) } \\
\text { - Core products are accessible from retailers (A3) }\end{array}$ & $\begin{array}{l}\text { - Risk for brand value of recovered } \\
\text { product quality } \\
\text { - Reverse flow volume } \\
\text { - Core product accessibility }\end{array}$ \\
\hline 5 & $\begin{array}{l}\text { - Technology in worn-out core products is too old for resale (B2 } \\
\text { and B4) } \\
\text { - Avoiding new component manufacturing through reuse gives } \\
\text { higher value that resale (B1) } \\
\text { - Avoiding down-time is crucial so exchanging defect products } \\
\text { with refurbished products is essential for sales (C1) } \\
\text { - All valuable components are customized, which limits the } \\
\text { number of potential customers (B1 and B3) } \\
\text { - Standard components entail too low value for recovery feasibility } \\
\text { (B1 and B3) }\end{array}$ & $\begin{array}{l}\text { - Product life cycle longevity } \\
\text { - Virgin product manufacturing cost } \\
\text { - Customers' valuation of RSC-enabled } \\
\text { services } \\
\text { - Degree of component customization } \\
\text { - Value of standard components }\end{array}$ \\
\hline 6 & $\begin{array}{l}\text { - For one product group virgin product manufacturing costs are too } \\
\text { low for recovery feasibility (B1-5) } \\
\text { - For defect virgin products the customer expects an exchange to a } \\
\text { new or recovered product (C1) } \\
\text { - Component value is too low for recovery feasibility (B1 and B3) }\end{array}$ & $\begin{array}{l}\text { - Virgin product manufacturing cost } \\
\text { - Customers' valuation of RSC-enabled } \\
\text { services } \\
\text { - Value of individual components } \\
\end{array}$ \\
\hline 7 & $\begin{array}{l}\text { - The value gap between core and recovered products is large (B1- } \\
\text { 5) } \\
\text { - The reverse flow of products is low (B1-5) } \\
\text { - Long product life-cycles make core products eligible for recovery } \\
\text { (B1 and B3) }\end{array}$ & $\begin{array}{l}\text { - Value gap between core and recovered } \\
\text { product } \\
\text { - Reverse flow volume } \\
\text { - Product life cycle longevity }\end{array}$ \\
\hline 8 & $\begin{array}{l}\text { - Products are highly customized to fit each customer, which } \\
\text { makes recovery and resale to different customers difficult (B4) } \\
\text { - Products are large and heavy and are located far away from } \\
\text { potential sorting and recovery facilities (A1-4, B1-5) } \\
\text { - The value of standard components is too low to justify recovery } \\
\text { and resale (B1 and B3) }\end{array}$ & $\begin{array}{l}\text { - Degree of product customization } \\
\text { - Core product “physics” } \\
\text { - Core product accessibility } \\
\text { - Value of standard components }\end{array}$ \\
\hline
\end{tabular}




\section{Revenue stream utilization pattern across cases}

Table 5 shows the cross-case analysis of revenue stream utilization. Case firms are located vertically and revenue streams horizontally. Each column shows revenue stream utilization within each firm, while each row shows utilization across firms.

Table 5 - Cross-case utilization pattern

\section{Case firms}

$\begin{array}{llllllll}1 & 2 & 3 & 4 & 5 & 6 & 7 & 8\end{array}$

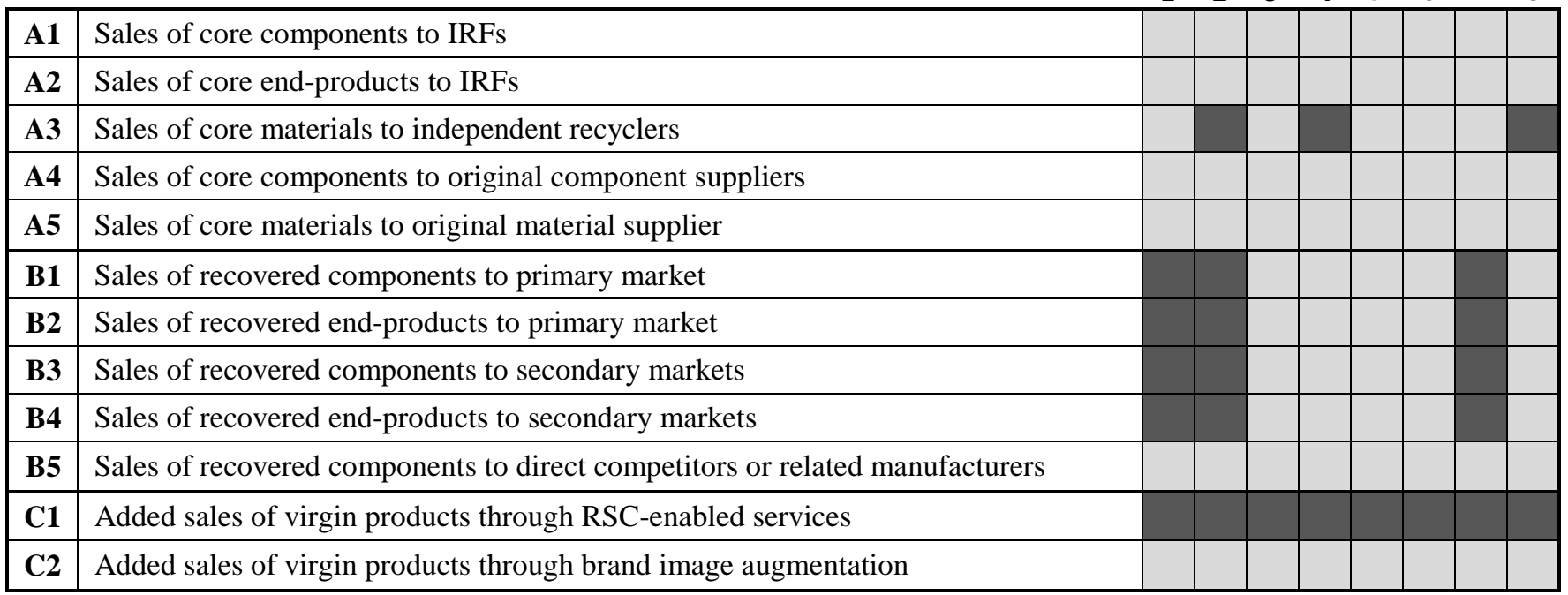

The table shows that streams A1-2 and A4-5 are un-utilized by all case firms and that A3 is utilized by three out of eight firms. The pattern for streams B1-4 is either utilization of all four streams or none. Stream C1 is utilized by all case firms, while B5 and C2 are un-utilized. In total, six of 12 streams are utilized. The following section links the pattern shown in Table 5 with the explanatory variables in Table 4.

\section{Explanatory variables for utilization pattern across cases}

This section uses the explanatory variables from the within-case analyses to develop a set of propositions that 1) explain the utilization pattern and 2) apply to firms within the entire domain limitation beyond the limits of the case sample.

Revenue streams A1-2 and A4-5 are not utilized by any case firms. The risk of brand value erosion caused by customers experiencing low quality of items recovered by an IRF applies with case 1 and 4, while a value of core items that is too low for justifying take-back applies with cases 1, 5, 6 and 8. Stream A3 is utilized by cases 2, 4, and 8. These three cases have large reverse flows of valuable materials, and although case 8's core products have large "physics", reverse logistical costs are reduced through resale to local recyclers.

For streams B1-4 the results suggest an "all-or-nothing” pattern. Cases 1, 2, and 7 utilize stream B1-4, while all remaining cases utilize none. Cases 1, 2 and 7 all sell high-priced products and are able to charge high prices for their recovered items, while core items have no value to customers. The resulting value gap between core and recovered items is large, which justifies the costs of reverse logistics, quality inspection, and recovery operations. In cases 1 and 7 virgin products are produced manually in low volumes suggesting a high internal cost of virgin product manufacturing compared to recovery. Cases 2 and 7 have long virgin product life-cycles, which elongates the window for sales of recovered products and components. All three firms have access to core items 
and knowledge of item whereabouts. The non-utilization of revenue stream B5 can be explained by the degree of component customization and low value of standard components. Customized components are difficult to reconfigure to new customers and the value of standard components (nuts and bolts) is for most firms low.

Category C shows a clear pattern: All firms use RSC-enabled services to increase revenue (C1), while no firm actively uses recovery to augment their brand image (C2). The variable that explains C1 utilization is customers' valuation of RSC-enabled services. These services are on the wish list of customers across all cases. Take-back of a defect product and replacement with a remanufactured product is an example of why a customer chooses a case firm's product over a competing product. The reason for the non-utilization of C2-revenue is less clear to interviewees. However, most case firms argued that a green brand image has a very low or no impact on customers' buying decisions.

Table 6 shows nine propositions that result from the cross-case analysis. The right-hand side column presents propositions, while the middle column links propositions to the case analysis.

Table 6 - Propositions

\begin{tabular}{|c|c|c|}
\hline & Reasoning linking proposition to case analysis & $\begin{array}{l}\text { Propositions explaining pattern in revenue } \\
\text { stream utilization }\end{array}$ \\
\hline $\mathbf{P 1}$ & $\begin{array}{l}\text { The firm may risk to erode their brand value if customers } \\
\text { experience low quality in IRF-recovered products }\end{array}$ & $\begin{array}{l}\text { A high risk of brand value erosion caused by } \\
\text { customers' experiencing low quality in IRF- } \\
\text { recovered items influences utilization negatively }\end{array}$ \\
\hline $\mathbf{P} 2$ & $\begin{array}{l}\text { A low reverse flow of core products makes the firm less } \\
\text { likely to implement RSC-processes }\end{array}$ & $\begin{array}{l}\text { A large reverse flow of core products influences } \\
\text { utilization positively }\end{array}$ \\
\hline P3 & $\begin{array}{l}\text { If customers place high value on recovered products and } \\
\text { low (or no) value on core products, the resale revenue } \\
\text { can supersede RSC-costs }\end{array}$ & $\begin{array}{l}\text { A high value gap between core and recovered } \\
\text { products influences utilization positively }\end{array}$ \\
\hline P4 & $\begin{array}{l}\text { If items are highly customized, the market for core or } \\
\text { recovered items is limited }\end{array}$ & $\begin{array}{l}\text { A high degree of product and component } \\
\text { customization influences utilization negatively }\end{array}$ \\
\hline P5 & $\begin{array}{l}\text { If virgin product manufacturing costs are high compared } \\
\text { to recovery, then recovery becomes feasible (assuming } \\
\text { prices for recovered items supersede RSC-costs) }\end{array}$ & $\begin{array}{l}\text { High virgin product manufacturing costs } \\
\text { influences utilization positively }\end{array}$ \\
\hline P6 & $\begin{array}{l}\text { If the firm has an accessible supply of core products, then } \\
\text { the costs of product acquisition are lower }\end{array}$ & $\begin{array}{l}\text { Accessibility of core products influences } \\
\text { utilization positively }\end{array}$ \\
\hline $\mathbf{P 7}$ & $\begin{array}{l}\text { If core products are large and heavy, then reverse } \\
\text { logistics costs will decrease the likelihood of profitable } \\
\text { recovery and resale }\end{array}$ & $\begin{array}{l}\text { Large dimensions and heavy weight of core } \\
\text { products influences utilization negatively }\end{array}$ \\
\hline $\mathbf{P 8}$ & $\begin{array}{l}\text { If products' life-cycle is long, the firm has a longer } \\
\text { window for reselling recovered products and components }\end{array}$ & $\begin{array}{l}\text { A long product life-cycle influences utilization } \\
\text { positively }\end{array}$ \\
\hline P9 & $\begin{array}{l}\text { If customers value RSC-enabled services, the firm can } \\
\text { achieve higher per-product revenue or win larger market } \\
\text { shares }\end{array}$ & $\begin{array}{l}\text { Customers placing high value on RSC-enabled } \\
\text { services influences the utilization positively }\end{array}$ \\
\hline
\end{tabular}

Whether logically available revenue streams are available in reality as well

Revenue streams A1-2, A4-5, and B5 are un-utilized by all case firms. The set of propositions suggests that these streams are unattractive because of the risk of brand value erosion, large core product "physics", and components' high degree of customization. However, the set of propositions help define potential future contexts within which pursuing these RSC-enabled revenue streams becomes worthwhile. For example, resale of core components to original component suppliers (A4) is not utilized by any case firm, but the set of propositions suggests that utilization is potentially feasible under the following conditions: 1) the OEM has access to a large reverse flow of core 
products; 2) these products are of low weight and have small dimensions; and 3) end-products have a long product life-cycle (that ensures the supplier a future market for recovered components).

\section{Conclusions and contribution to theory and practice}

The paper's results show twelve distinct RSC-enabled revenue streams within three categories: A) new revenue through sales of core items, B) new revenue through sales of recovered items, and C) new revenue through added sales of virgin products. The case sample results show that six of these twelve revenue streams are utilized in industrial practice and that the utilized streams primarily are within category $\mathrm{B}$. The paper presents nine propositions that explain the revenue stream utilization for firms within the paper's domain limitation. The following set of characteristics summarizes the set of propositions by describing the OEM that most likely will utilize RSC-enabled revenue streams. The OEM has:

- Easy access to core products and can build up a large reverse flow

- A high value gap between core and recovered items

- A low degree of product and component customization

- High virgin product manufacturing costs compared to recovery costs

- Core products with small physical dimensions and low weight

- A low risk of brand value erosion if IRFs were to recover their products with quality requirements lower than the OEM

- Customers that value RSC-enabled services

\section{Contribution to theory}

As mentioned in the paper's introduction, the traditional RSC-view that the RSC a necessary evil directs research towards cost reduction goals. By contrast, this paper views the RSC as a value creator. The paper contributes to the RSC business perspective by detailing 1) how OEMs can generate revenue through their RSC and 2) which factors influence whether pursuing RSC-enabled revenue streams is worthwhile. The vast majority of those papers that address RSC-enabled revenue focus on the revenue stream "recovery and resale to the firm's primary market”. By contrast, this paper contributes to the RSC-literature by broadening the set of RSC-enabled revenue streams to include unexplored revenue streams. Examples are 1) resale of core materials to original suppliers, and 2) resale of recovered components to direct competitors or related manufacturers. A key contribution is broadening the set of buyer groups for items processed in the firm's RSC.

In addition to contributing to the RSC business perspective literature, the paper extends the literature streams on disposition strategy choice, remarketing, and the prerequisites for financial success of the RSC. The paper extends the work of Skinner et al. (2008) and Hazen et al. (2012) that investigates disposition strategy choice. The paper extends their work by broadening the set of disposition strategy options to include utilization of new revenue streams as decision outcomes. The paper contributes to the theory on remarketing (e.g. Atasu et al., 2010) by providing a comprehensive set of remarketing opportunities. Guide and Van Wassenhove (2009) argue that there are three prerequisites for RSC-success: Accessing enough recoverable core products, being able to recover them at a reasonable cost, and developing markets for the recovered products. These prerequisites address the processes inherent in RSC itself. The propositions developed in this paper support these three prerequisites, but extend the set by including issues that are contextual to the RSC. Examples are how customers value RSC-enabled services when making purchasing decisions and whether the life-cycle of virgin products is long.

In addition to increasing the understanding of the RSC concept, the paper contributes to the understanding of terms related to the RSC as well. Examples are "closed-loop supply chain" (CLSC), "product recovery management" (PRM), and "reverse logistics" (RL). Both the definitions of CLSC and PRM (Thierry et al, 1995; Guide and Van Wassenhove, 2009) pair the physical RSC 
with the purpose of operating it. As the purpose for operating a RSC the CLSC concept advocates "maximizing value" across the entire life-cycle of a product, while PRM advocates "recovering value". Within both concepts the nuts-and-bolts operating system that conducts the recovery cycles that maximize/recover value appears to be the five processes that constitute the RSC. Therefore, a contributing to the understanding of the RSC concept implicates a contribution to the CLSC and PRM concepts as well. Concerning RL, this paper applies a narrow definition (reverse transportation and inventory). However, several scholars (including a number of references within this paper's literature review) use a broader RL-definition that roughly equates this paper's RSCdefinition. Therefore, the paper essentially makes the same contribution to both the RSC-concept and the broader RL-concept.

\section{Contribution to practice}

Overall, the paper supports the effort to recast the role of the RSC from "the unwanted stepchild" to a driver of value. Using the paper's results, managers are able to select the revenue streams that the firm should utilize. Some managers may conclude that the firm already utilizes all relevant revenue streams, while other may find unexplored business opportunities. In general, the paper recommends a process with the following steps to identify profitable revenue stream utilization:

1. Use the set of streams from this paper to identify which revenue streams the firm currently utilizes

2. Use the set of propositions that indicate when streams are feasible pursuing to examine which un-utilized streams have potential for profitable utilization

3. Set prices for all sellable items, estimate sales volumes, and assess revenue

4. Identify the RSC-processes involved in all chosen revenue streams and assess costs

5. Assess profitability of the RSC

Although the study's domain is limited to OEMs, the paper's findings contribute to practitioners from several other types of firms. IRFs are able to resell recovered end-products and components to the OEM's primary and secondary markets (B1-4), and to the OEM's direct competitors and related manufacturers (B5). Retailers and distributors can resell core end-products to IRFs (A2) and (with in-house disassembly capabilities) resell core components and materials to original suppliers and independent recyclers (A1 and A3-5). Furthermore, component manufacturers can resell core materials upstream (A3 and A5) and recovered components downstream (B5). Cooperation about RSC-processes across the supply chain can potentially strengthen interfirm relations, as for example reverse factoring (Lekkakos and Serrano, 2016).

\section{Limitations and future research opportunities}

The paper's findings are found using a literature-based analytical approach and a multiple case study of eight firms of which only three have experience with more than two revenue streams. The limitations inherent in this approach opens up several future research opportunities to further examine the relationship between the RSC and the firm's revenue. Suggestions are: 1) a similar study that adds utilization experience as an explicit case selection criterion; 2) a case study that applies a replication strategy using one or more of the factors contained in the paper's propositions as variables (e.g. the value-gap size, product life-cycle longevity, or core product accessibility); and 3) survey research that tests the relationship between revenue stream utilization and the propositions. The latter may identify additional revenue streams that this study has not captured.

While the paper has identified the opportunities for new revenue, the question of profitability inherent in each revenue stream remains unexplored. There are research opportunities to examine the profit-potential within revenue streams, investigating which factors inhibit and advance profitability. Much extant literature has focused on issues related to minimizing reverse logistics 
costs (e.g. network design, collection modes, and inventory management). The question, which future research could examine, is whether these factors are decisive for profitability within RSCenabled revenue stream utilization (or perhaps just more researchable).

In addition to the research opportunities that directly follow this study, the paper suggests research on managerial issues related to revenue stream utilization. For example competition concerns relevant for firms deciding to sell core products to IRFs, the risks in selling core end-products (e.g. cannibalization), and contractual design issues related to resale of core items to IRFs.

\section{References}

Aaker, D. (1991), Managing Brand Equity - Capitalizing on the Value of a Brand Name, The Free Press, New York, NY

Atasu, A., Guide, V.D.R. and Van Wassenhove, L. (2010), "So what if remanufacturing cannibalizes my new product sales", California Management Review, Vol. 52 No. 2, pp. 56-76. Atasu, A., Guide, V.D.R. and Van Wassenhove, L. (2008), "Product Reuse Economics in ClosedLoop Supply Chain Research", Production and Operations Management, Vol. 17 No. 5, pp. 483496.

Barratt, M., Choi, T.Y. and Li, M. (2011), “Qualitative case studies in operations management: Trends, research outcomes, and future research implications", Journal of Operations Management, Vol. 29 No. 4, pp. 329-342.

Chan, H., He, H. and Wang, W. (2012), "Green marketing and its impact on supply chain management in industrial markets", Industrial Marketing Management, Vol. 41 No. 4, pp. 557-562. Chen, J.M. and Chang, C.I. (2012), "The co-opetitive strategy of a closed-loop supply chain with remanufacturing", Transportation Research Part E: Logistics and Transportation Review, Vol. 48 No. 2, pp. 387-400.

Clottey, T. and Benton, W. (2014), "Determining core acquisition quantities when products have long return lags”, IIE Transactions, Vol. 46 No. 9, pp. 880-893.

Cohen, M.A., Agrawal, N. and Agrawal, V. (2006), "Winning in the aftermarket", Harvard Business Review, Vol. 84 No. 5, pp. 129-138.

da Mota Pedrosa, A., Näslund, D. and Jasmand, C. (2012), "Logistics case study based research: towards higher quality”, International Journal of Physical Distribution and Logistics

Management”, Vol. 42 No. 3, pp. 275-295.

Debo, L., Toktay, L. and Van Wassenhove, L. (2006), "Joint Life-Cycle Dynamics of New and Remanufactured Products”, Production and Operations Management, Vol 15 No. 4, pp. 498-513. Ferrer, G. and Swaminathan, J. (2006), "Managing new and remanufactured products", Management Science, Vol. 52 No. 1, pp. 15-26.

Geyer, R. and Jackson, T. (2004), "Supply loops and their constraints: the industrial ecology of recycling and reuse", California Management Review, Vol. 46 No. 2, pp. 55-73.

Guide, V.D.R. and Pentico, D. (2003), "A hierarchical decision model for re-manufacturing and reuse", International Journal of Logistics, Vol. 6 No. 1-2, pp. 29-35.

Guide, V.D.R. and Van Wassenhove, L. (2006), "Closed-Loop Supply Chains: An Introduction to the Feature Issue (Part 1)", Production and Operations Management, Vol. 15 No. 3, pp. 345-350. Guide, V.D.R. and Van Wassenhove, L. (2009), "The Evolution of Closed-Loop Supply Chain Research”, Operations Research, Vol. 57 No. 1, pp. 10-18.

Gungor, A. and Gupta, S. (1999), "Issues in environmentally conscious manufacturing and product recovery: a survey”, Computers \& Industrial Engineering, Vol. 36 No. 4, pp. 811-853.

Hazen, B., Hall, D. and Hanna, J. (2012), "Reverse logistics disposition decision-making: developing a decision framework via content analysis", International Journal of Physical Distribution and Logistics Management, Vol. 42 No. 3, pp. 244-274. 
Huscroft, J., Hazen, B., Hall, D., Skipper, J. and Hanna, J., (2013), "Reverse logistics: past research, current management issues, and future directions", The International Journal of Logistics Management, Vol. 24 No. 3, pp. 304-327.

Ilgin, M. and Surendra, G. (2010), "Environmentally conscious manufacturing and product recovery (ECMPRO): A Review of the State of the Art”, Journal of Environmental Management, Vol. 91 No. 3, pp. 563-591.

Jack, E., Powers, T. and Skinner, L. (2010), "Reverse logistics capabilities: antecedents and cost savings”, International Journal of Physical Distribution and Logistics Management, Vol. 40 No. 3, pp. 228-246.

Jayaraman, V. and Luo, Y. (2007), "Creating Competitive Advantages through New Value Creation: A Reverse Logistics Perspective”, Academy of Management Perspectives, Vol. 21 No. 2, pp.56-73.

Karlsson, C. (2003),"The development of industrial networks: challenges to operations management in an extraprise", International Journal of Operations and Production Management, Vol. 23 No. 1, pp. 44-61.

Ketokivi, M. and Choi, T. (2014), “Renaissance of case research as a scientific method”, Journal of Operations Management, Vol. 32 No. 5, pp. 232-240.

Kocabasoglu, C., Prahinski, C. and Klassen, R. (2007), "Linking forward and reverse supply chain investments: The role of business uncertainty”, Journal of Operations Management, Vol. 25 No. 6, pp. 1141-1160.

Kotler, P. (2000), Marketing management: The millennium edition, Prentice Hall, New York, NY Kotler, P. and Keller, K.L. (2009), A Framework for Marketing Management, 4th edition, Pearson Prentice Hall, New York, NY

Lee, C. and Lam, J. (2012), "Managing reverse logistics to enhance sustainability of industrial marketing", Industrial Marketing Management, Vol. 41 No. 4, pp. 589-598.

Lekkakos, S. and Serrano, A. (2016), "Supply chain finance for small and medium sized enterprises: the case of reverse factoring", International Journal of Physical Distribution \& Logistics Management, Vol. 46 No 4, pp. 367-392

Liebl, J., Hartmann, E. and Feisel, E. (2016), "Reverse factoring in the supply chain: objectives, antecedents and implementation barriers", International Journal of Physical Distribution \& Logistics Management, Vol. 46 No 4, pp. 393-413.

Meredith, J. R., Raturi, A., Amoako-Gyampah, K. and Kaplan, B. (1989), “Alternative research paradigms in operations”, Journal of Operations Management, Vol 8 No 4, pp. 297-326.

Meredith, J. (1993), “Theory building through conceptual methods”, International Journal of Operations and Production Management, Vol. 13 No. 5, pp. 3-11.

Miles, M., Huberman, A. and Saldaña, J. (2014), Qualitative data analysis: A methods sourcebook, SAGE Publications, Thousand Oaks, CA

Mollenkopf, D. and D. Closs (2005), “The Hidden Value in Reverse Logistics”, Supply Chain Management Review, Vol. 9 No. 5, pp. 34-43

Mollenkopf, D., Russo, I. and Frankel, R. (2007), "The returns management process in supply chain strategy", International Journal of Physical Distribution and Logistics Management, Vol. 37 No.7, pp. 568-592.

Oliva, R. and Kallenberg, R. (2003), "Managing the transition from products to services", International Journal of Service Industry Management, Vol. 14 No.2, pp. 160-172. Pagell, M., Wu, Z. and Murthy, N. (2007), "The supply chain implications of recycling", Business Horizons, Vol. 50 No. 2, pp. 133-143.

Prahinski, C. and Kocabasoglu, C. (2006), "Empirical research opportunities in reverse supply chains", Omega, Vol. 34 No. 6, pp. 519-532. 
Robotis, A., Bhattacharya, S. and Van Wassenhove, L. (2005), "The effect of remanufacturing on procurement decisions for resellers in secondary markets", European Journal of Operational Research, Vol. 163 No 3, pp. 688-705.

Simpson, D. (2010), “Use of Supply Relationships to Recycle Secondary Materials”, International Journal of Production Research, Vol. 48 No. 1, pp. 227-249.

Souza, G.C. (2012), "Closed-Loop Supply Chains: A Critical Review, and Future

Research", Decision Sciences, Vol. 44 No. 1, pp. 7-38.

Skinner, L., Bryant, P.T. and Richey, R.G. (2008), "Examining the impact of logistics disposition strategies”, International Journal of Physical Distribution and Logistics Management, Vol. 38 No. 7, pp. 518-539.

Srivastava, S. and Srivastava, R. (2006), "Managing product returns for reverse logistics", International Journal of Physical Distribution and Logistics Management, Vol. 36 No. 7, pp. 524-546.

Stock, J., Speh, T. and Shear, H. (2002), “Manny Happy (Product) Returns”, Harvard Business Review, Vol. 80 No.7, pp. 16-17.

Tang, C. (2010), “A review of marketing-operations interface models: From co-existence to coordination and collaboration”, International Journal of Production Economics, Vol. 125 No. 2, pp. 22-40.

Thierry, M., Salomon, M., Van Nunen, J. and Van Wassenhove, L. (1995), ”Strategic Issues in Product Recovery Management”, California Management Review, Vol. 37 No. 2, pp. 114-135. Tibben-Lembke, R. (2004), "Strategic use of the secondary market for retail consumer goods", California Management Review, Vol. 46 No. 2, pp. 90-104.

Voss, C., Tsikriktsis, N. and Frohlich, M. (2002), "Case research in operations management”, International Journal of Operations and Production Management, Vol. 22 No. 2, pp.195-219. Wacker, J. (1998), "A definition of theory: research guidelines for different theory-building research methods in operations management", Journal of Operations Management, Vol.16 No. 4, pp. 361-385.

Yin, R. (2014), Case study research: Design and methods, Sage publications, Thousand Oaks, CA 